\title{
Writing outside history: Reification, agency and the discourse on identity and difference
}

\begin{abstract}
The recent debates about the transformation, or decolonization, of higher education in South Africa have underscored the continuing salience of "identity" in post-apartheid political discourse. Disillusioned with the token equality of liberal politics, student-led movements now demand that their manifestos be granted legitimacy precisely on particularistic grounds. With the aim of understanding what conception of social change these demands entail, this archival study analyzes how political identity and agency have been constructed in contemporary South African academic discourse. More specifically, this study identifies the different kinds of ontological and epistemological presuppositions that particular uses of language are necessarily committed to, and therefore necessarily limited by (both politically and conceptually). Utilizing Scopus, a bibliographic database, the five most relevant and highly cited articles were selected and subsequently analyzed using the logical rules governing both predicate ascription and presupposition. Two main uses of language were isolated based on common sets of presuppositions: 1) A non-human ontology of agents, and 2) Agency as a property of antecedently given identities. Each use of language was found to comprise two further subcategories respectively: 1.1) Psychological agencies, 1.2) External agencies; and 2.1) Realist view of political identity, 2.2) Constructivist view of political identity. The results of the data analysis suggest that the two main uses of language are mutually reinforcing. Taken together, they appear to entail an account of social change that, via the linguistic obfuscation and reification of human agency, is in
\end{abstract}

\footnotetext{
1 This article is based on research conducted by Raphael Mackintosh, and supervised by Wahbie Long.
}

\author{
Raphael Mackintosh ${ }^{1}$ \\ \& Wahbie Long \\ Department of Psychology \\ University of Cape Town \\ Rondebosch 7700
}

\section{Keywords}

political identity, agency, ontology, social change, decolonization, reification, metapsychology 
fact immanent to the existing socio-political order itself. It is suggested that future research on political identity and agency will require a trans-disciplinary approach concerned with explaining manifest social antagonisms (e.g. class oppression; institutional racism; Islamophobia) in terms of the global historical and material conditions within which they are located.

\section{Introduction}

Over the last two years, the impassioned set of debates taking place across South African universities have since drawn sharp attention to certain matters of social justice and inequality affecting higher education in South Africa; white privilege, black pain and the post-apartheid requisite for decolonized knowledge production expressing the vox populi in most cases (Long, 2015). The renewed discourse on transformation, originating within student-led movements such as Rhodes Must Fall (RMF), has increasingly been shaped by what Taylor coined as the "politics of recognition": a discourse that grants political legitimacy to individuals and groups on the sociohistorical basis of their identities (Taylor, 1994: 25). Owing to its hierarchical demarcation of social identities (as defined by their relative sociohistorical privilege), one consequence of any politics of identity-recognition is a scepticism regarding the exercise of agency beyond the distinct, and relative borders of identity per se e.g. the ethically questionable involvement of white people in anti-racist struggles (Hook, 2011). Given that, as Long (2015) notes, current student manifestos are drawing substantially, albeit selectively, from history's revolutionary intelligentsia, there remains a need to redirect our analytic curiosity toward the present historical moment in order that the spotlight be shone on the role of contemporary South African academics in shaping this particular discourse. Notwithstanding the arguments occurring at the already seasoned level of sociopolitical theory, considerably less attention has been paid to the philosophical and conceptual relationships between identity, agency and political life upon which the current discourse on transformation necessarily depends upon for its cogency.

The literature on political identity and its relationship to both individual and group agency is theoretically complex. I therefore organized its content by utilizing what Kaniki (1999: 19) calls a thematic review: "a review structured around different themes or perspectives in the literature, often focusing on the debates between different 'schools.' My primary interest in this review concerns the theoretical and philosophical relationships between "identity" and "agency" within political life.

\section{The recent historical importance of identity in politics}

Identities, both personal and social, are nowadays recognized as fundamentally important aspects of all social and political inquiry (Frueh, 2003; McQueen, 2015). However, there is a split in academic consensus between those who lament the 
commodification of identity (i.e. when systemic problems are recast using identity as the primary site of social antagonism), and those who regard the relevance of identity as indispensable to political struggle (Sharansky, 2008). One example of the latter opinion was second wave feminism which, during the second half of the $20^{\text {th }}$ century, reacted to the homogenizing effects that pre-identitarian forms of liberal culture had had on previously marginalized social groups (Taylor, 1994). Through what Hegel famously coined as "the struggle for recognition" - i.e. the reclamation of, and demand for, social recognition - the politicization of identity has since become a crucial part of the demands of historically oppressed groups (Heyes, 2014, para. 10). As this pattern indirectly shows, the normative and political power of one's social identity depends upon particular descriptive presuppositions of the human subject (Frueh, 2003). This raises philosophical questions about the nature and scope of human agency, and the sociality and construction of identity. In many cases, what prima facie appear to be moral incompatibilities between different political theories of the subject, are instead a product of their distinct ontological assumptions regarding human nature itself (Frueh, 2003).

\section{The ontological status of the subject, identity \& agency}

There are two major views about the ontological status of the human subject in Western history, the second of which found widespread acceptance during the $20^{\text {th }}$ and $21^{\text {st }}$ century in existentialist, psychoanalytic, feminist and post-structuralist theories of political identity (Häkli \& Kallio, 2014). The first view originates from the thought of two Western philosophers, namely Rousseau and Kant (Taylor, 1994). Inspired largely by Rousseau's writing, the notion of self-authenticity as an inner moral process of following the voice of nature began to form an essential part of individual identity (Ansell-Pearson, 1991; Taylor, 1994). The autonomous, self-sufficient and "bounded" self - free from any social or historical constraints - became central to liberal (Western) thought by the early $19^{\text {th }}$ century (Ansell-Pearson, 1991: 273). Similarly, Kant insisted that political life must always pay homage to the primacy of the rational individual, the ontological status of which is both pre-social and universally assumed (Ansell-Pearson, 1991; McQueen, 2015). Unsurprisingly, this liberal conception of the self has been criticized as a mere formalistic and metaphysical abstraction that "purchases moral autonomy ... at the cost of excluding all historical and psychological determination" (Ansell-Pearson, 1991: 274). Against the atomistic view of the pre-social self, there emerged a profoundly intersubjective conception of selfhood (Häkli \& Kallio, 2014). Hegel, the author of this view, criticized Rousseau's insistence for a unity of purpose at the heart of political life, and argued that the assumption that all humans share some pre-social identity ends up granting citizens nothing more than token equality. In this regard, Hegel's insight was to conceptualize selfhood as being dependent on recognition (Häkli \& Kallio, 2014; McQueen, 2015). In contrast to the self as something antecedently given, Hegel 
argued that the self emerges, as both a political subject and moral agent, through a process of recognition by the "other" (McQueen, 2015). As he famously asserted, "self-consciousness exists in itself and for itself, in that, and by the fact that it exists for another self-consciousness; that is to say, it is only by being acknowledged or 'recognized'" (Hegel, 1807 as cited in McQueen, 2015: 53). If the self's very existence and capacity for agency is extrinsically (as opposed to intrinsically) determined, so it follows that one's political identity is contingent upon both receiving and conveying affirmative modes of recognition (McQueen, 2015).

In sharp contrast, Nietzsche and Lacan have provided the groundwork for the postmodern conception of identity and selfhood, which was especially influential in $20^{\text {th }}$ century political theory (Heyes, 2014). Nietzsche's conception of the self discloses it as a radically historical and cultural entity (McQueen, 2015). For Nietzsche, there is no metaphysical entity lurking beneath the human agent, no essential "doer" who "does" (Ansell-Pearson, 1991). The self is a meaningless abstraction if it is not understood as the product of an interpretative act; one in which it is reflexively created, and so positioned, as that to which we attribute the exercise of power. In other words, the "I" only exists through the exercise of a pre-given agency, through "power organized as subjectivity" (Warren, 1988, as cited in Ci, 2011: 262).

Similarly, Lacan, in his paper "The mirror stage as formative of the I" (1949), argued that identity is necessarily decentred. Following Freud, Lacan claimed that the behaviour of infants show that they do not have a sense of individuated identity. Inevitably, when the infant experiences the discrepancy between its inner needs and the external source of their gratification, it is confronted with "the fact of otherness" (Lacan, 1949). Consequently, it is the infant's desire for wholeness which is also the precondition for its sense of self. For Lacan then, identities represent projective fantasies of wholeness - an intersubjectively similar, yet ontologically distinct, view from Hegel.

The poststructuralist and interpretative approaches during the $20^{\text {th }}$ century both accepted some variant of the Hegelian intersubjective process of identity formation (Häkli \& Kallio, 2014). For poststructuralists such as Derrida, Foucault and Butler, identities, whether or not imposed, represent oppressive attachments to particular social categories that have themselves been constructed through and by hegemonic networks of power (Frueh, 2003; McQueen, 2015). In light of this framework, Butler, following Foucault, argued that gender identity is a performative accomplishment that is inevitably circumscribed by its behavioural and discursive conformity to historical, institutional norms (McNay, 2010). Addressing the issue of agency, she argues that resisting the imposition of identity involves a glaring paradox: identities - because they are prescriptive (dictated by power) - always fail to fully describe individuals, and yet it is precisely this failure which 
creates the possibility for resistance, since it is only through being (mis)named that the subject is created in the first place (Alcoff, 2000).

Within the interpretative tradition, I include theories of recognition (Charles Taylor), existential phenomenology (Hannah Arendt; Frantz Fanon) and pragmatism (George Herbert Mead). Common to all these branches is a dissatisfaction with poststructuralism's abstract, discursive conception of the subject (McQueen, 2015). Taylor (1995) argued that Nietzsche's influence on poststructuralism resulted in a rejection of any "extra-discursive" self; one to which the properties of authenticity, agency and temporal durability may be ascribed. Conversely, Taylor (1994) views the central theme in contemporary politics as being expressed by the demand for recognition, a demand that requires the invocation of identity as a dimension of embodied experience, and which therefore construes (political) agency as more than simply the result of a discursive paradox. Theories of recognition such as Taylor's (see also Honneth, 1995) explain the oppression of marginalized groups in terms of misrecognition, or non-recognition, namely the purposeful withholding of recognition (Häkli \& Kallio, 2014). Fanon (1952, as cited in McQueen, 2015) expressed this point powerfully, arguing that it was precisely the inability of colonized peoples to self-determine their identity - to obtain recognition - that imprisoned them in a psychologically distorted mode of being. Thus recognition theories tend to locate the source of individual and collective (political) agency in the constitutive power of recognition itself (McQueen, 2015).

Lastly, following Mead's (1934, as cited in Häkli \& Kallio, 2014) theory of identity formation, Häkli and Kallio suggest that individuals only ever become conscious of themselves in the object-position. The object of this self-reflexive perception is what Mead refers to as the subject's social self or (intersubjectively constituted) "me". In contrast, the subject of this self-reflexive perception is the phenomenological "I": "the elusive ongoing agency that the subject cannot experience directly precisely because 'I' is not an object" (Häkli \& Kallio, 2014, p.187). Hence, although agency is only a property of already socially (and politically) existent subjects (the "me"), the act of relating to the world is carried out by the subject's "I" - the source of human agency (Häkli \& Kallio, 2014). Accordingly, the exercise of agency cannot be explained by a facile voluntarism (as in the liberal conception), a fully determined social process (as in theories of recognition), or a mere relation between discursively constituted subjects and their identities (as in poststructuralism).

As this brief thematic review shows, the myriad ways in which (political) identity and agency are theorized directly impact the limits of individual and group action in society, since language "does" by conditioning the limits of discourse, and therefore of social 
action too (Frankenberg, 1993). This point applies to academic scholarship as a whole. However, thus far, no archival research has examined the philosophical and conceptual relationships between political identity and agency in recent South African scholarship. Indeed, given that the intellectual engine driving the recent waves of student protest comprise arguments dealing with the possibility of white anti-racism, transformative justice, whiteness, and the politics of identity, there likewise exists a pertinent political reason to critically analyze this literature precisely in view of the power that language has to shape, explain or indeed obscure reality (Fairclough, 2003).

\section{Aim and research question Aim and significance}

The motivation for this research derives from an acknowledgement of the commitment to human freedom and agency which narrative analysis, liberation psychology and Marxism all adopt at their core, but which is perhaps best expressed by the existentialist maxim, "existence precedes essence" (Allen, 2002: 135). Specifically, a lived commitment to non-essentialized modes of being must equally entail problematizing any language which, instead of humanizing the empirical world in the interests of liberation and social mobility, often accomplishes the opposite: that is, a language which 1 ) regularly dehumanizes people through mechanistic causal explanation, 2) obscures human agency through reification, personification and anthropomorphism, and 3) pathologizes individuals as the helpless victims of either intrapsychic or socially predetermined causes (Stern, 1967; Petrović, 1983). Consequently, this study aims to determine whether the language used to describe political identity and agency within contemporary South African academic texts functions in any of the abovementioned ways, and, if so, to what extent this supports a discourse on transformation and social change that is effectively discontinuous with the material, economic and historical conditions of which it is a product.

\section{Main research question}

How does contemporary South African academic discourse about transformation construct political identity and agency?

\section{Sub-questions}

- (Linguistic) Is agency being described as a property of humans/people?

- (Ontological) What kind of relationship between identity and agency do the various uses of language presuppose?

- (Ideological) Is there strong evidence to suggest that identity-related terms (e.g. whiteness) are being reified and/or described in anthropomorphic terms? 
- (Historico-political) Overall, what does the use of language in current academic discourse suggest about the broader political climate in post-apartheid SA?

\section{Theoretical framework}

This study is informed by a set of ontological and epistemological assumptions which, in social science research, fall roughly under the theoretical framework of "Critical Realism" (CR) (Fairclough, 2003: 13). This approach has two defining features: epistemological relativism and ontological realism. In relation to the archival focus of this study, I follow Fairclough's (2003: 14) claim that "reality (the potential, the actual) cannot be reduced to our knowledge of reality, which is contingent, shifting, and partial". In other words, our knowledge of a particular text is never exhaustive, since no analysis can be epistemologically comprehensive. This is what is meant by epistemological relativism. Moreover, in the CR tradition, the use of language is seen as a form of social practice that is intimately connected with broader ideological and power structures (Nabers, 2015). In this regard, I will be paying particular attention to those uses of language in which meaning is temporally fixed via presupposition (Nabers, 2015). Such an approach is appropriate, since presuppositions not only assume a common ground of knowledge, but also "force" one to assume such knowledge on behalf of the argument made by the author.

As Culler (1976) notes, one need not focus on the fact that something is presupposed; rather, one should be interested in what these presuppositions enable, ignore or treat as unproblematic. Lastly, it is worth mentioning that a realist ontology does not in fact suffice with respect to the purposiveness of this study. This is because I consider the question of what is "out there", in terms of a mind-independent reality, as an irrelevant pursuit, as objectivity in social science is today scarcely more than a positivist shibboleth (Yule, 1996). Rather, this study assumes a position closer to the ontological agnosticism of Pragmatist approaches which suggest that what matters has less to do with truth, or subjective varieties thereof, than with a way of knowing which both enhances "life" (e.g. our agency) and which allows for the progressive revision of useful knowledge - a de facto political position (Yule, 1996).

\section{Method}

\section{Research design}

Archival research

Archival data refers to information that is already stored, gathered, organized or systematized for reasons unrelated to the research at hand (Goodwin, 2010). For the purposes of this study, the archival material was sourced from computerized databases using EBSCOHost, an online reference system which primarily stores electronic articles and academic publications for research purposes. Given the qualitative nature of this 
study, the archival material was purposefully selected on the basis of its relevance to the research questions - which focus on discussions and/or arguments involving identity-related terms (e.g. whiteness, blackness, (non)racialism etc.) and their relationship to the political sphere (e.g. anti-racism, multiculturalism, ideology, apartheid etc.) (Barnard-Wills, 2012). Moreover, textual analysis is well-suited to social and political research for a number of reasons: as Barnard-Wills (2012: 81-82) argues concerning political identities, "texts are good indicators of social change ... in this case the reconstruction and re-articulation of social identities ... [their] availability is also a strength, especially compared with interviews". Lastly, the unobtrusive nature of archival research is considered an advantage of its design since the researcher does not face problems related to participant reactivity (Goodwin, 2010).

\section{Data collection tool and procedures}

Treating text as the unit of analysis, the data collection method is likewise the sampling method in this study (Fairclough, 2003). Using an Elsevier owned bibliographic database called Scopus, which calculates the number of scholarly citations per academic publication, an initial set of texts was selected according to two general criteria: i) theoretical relevance to the research question(s) (i.e. keywords that made reference to identity, agency, politics and social change), and ii) the highest number of scholarly citations. However, this study's focus is on contemporary South African academia, and so the resulting texts were filtered further according to: i) date of publication (texts published prior to 2005 were excluded) and ii) the prioritization of the South African context. On the basis of these sampling criteria, the following articles were selected (listed here in descending order of citation count): a) "Beyond the optimal contact strategy: A reality check for the contact hypothesis" (Dixon, Durrheim \& Tredoux, 2005); b) "Sex, death and the fate of the nation: Reflections on the politicization of sexuality in post-apartheid South Africa" (Posel, 2005); c) "Repertoires for talking white: Resistant whiteness in post-apartheid South Africa" (Steyn \& Foster, 2008); d) "How do I live in this strange place?” (Vice, 2010); e) “A critical psychology of the postcolonial” (Hook, 2005).

\section{Data analysis}

Combining the analysis of presupposition and entailment in Yule's (1996) Pragmatics with Fairclough's (2003) concept of nominalization, this study analyzed different uses of language - apropos identity, agency and their political interrelation - as they related to the abovementioned research questions (please see Appendix $A$ for details regarding nominalization, and the semantic/logical rules associated with the orthodox definition of presupposition). To be precise, what distinguishes one use of language (one "language game") from another are the different kinds of presuppositions necessary for the relevant utterances, expressions or statements to be meaningful (Yule, 1996). As such, what emerged from the dataset were not distinct "themes" i.e. recurrent and 
meaningful references to specific subjects or ideas (Sher \& Long, 2012). Rather - at the pragmatic level of utterance - the data was analyzed, and subsequently categorized, according to the different kinds of presuppositions - and therefore the different uses of language - embedded within the general discourse on political identity and agency.

Moreover, as previously suggested, because presuppositions constitute an assumed background knowledge, they are liable to be used ideologically. In this regard, I utilized a definition of "ideology" that encompasses two distinct, albeit related, interpretations: i) as comprising "representations of aspects of the world which can be shown to contribute to... maintaining social relations of power, domination and exploitation" (Fairclough, 2003: 9); and ii) as a kind of "tacit denial that ideas and beliefs are specific to a particular time, place and social group" (Eagleton, 1991: 59). The former interpretation concerns the political function of ideology in maintaining broader exploitative social relations, while the latter portrays it as a species of presentist thinking whereby social phenomena are conceived of as natural, inevitable and self-determining (i.e. beyond the scope of human agency) (Eagleton, 1991).

Consequently, and in line with the research questions, the present analysis focused specifically on those uses of language where the validity of certain ontological, epistemological and moral viewpoints was not only presupposed, but treated as self-evident, inevitable and unchanging (notice how this does not imply an interest in the pursuit of objective truth, but rather an interest in the conditions of possibility for intelligible and/or meaningful language use). Explicating the conceptual interrelationships between these different levels of analysis (i.e. ontology, epistemology, ethics) - as they relate to identity, agency and politics - thus became crucial to answering the research questions posed by this study.

\section{Limitations and reflexivity}

The narrow range of academic publications analyzed may constitute a representative limitation of this study. However, the fact that all these papers have high citation counts means that, in some sense, they already characterize the academic ethos of a particular "discourse community" (Porter, 1986: 38). Furthermore, although this study's results have limited relevance beyond the institutions of higher learning in South Africa, the important sociopolitical influence these institutions exert cannot be discounted. Regarding my own personal biases, I remain unconvinced by the identity-based politics permeating both academic curricula and student discourse. Indeed, I tend to agree with Zizek - commenting on Chibber's (2013) Postcolonial theory and the specter of capital, that "with its focus on cultural identities and mixtures, postcolonial theory ignored the larger context of capitalist relations and thus limited its scope to Western academia where it excelled in the game of growing and profiting from the liberal guilt 
feeling" (Zizek, 2013). Nonetheless, I endeavour to remain as charitable to the arguments encountered as my liberal white male cis-gendered and heterosexual self will permit.

\section{Data analysis and discussion}

\section{Structure}

The following analysis consists of two main categories that reflect two fundamentally different uses of language. The distinction between these main categories hinges on whether agency is presupposed as a property exclusive to humans. Each main category is comprised of two further subcategories, which reflect more nuanced variations at the level of language use and presupposition. The structure of the analysis is therefore as follows: a) an ontology of non-human agents (category 1): i) psychological agencies (subcategory 1), ii) external agencies: nominalization and anthropomorphism (subcategory 2); b) agency as a property of antecedently given identities (category 2): i) realist view of political identity (subcategory 3 ), ii) constructivist view of political identity (subcategory 4).

\section{Category 1: An ontology of non-human agents}

The first main category refers to the use of language whereby agency is attributed, not to people, but to reified entities/processes that are either "internal" and psychological (the first subcategory) or "external" and empirical (the second subcategory). The use of this language presupposes the existence of a non-human ontology of agencies.

\section{Psychological agencies}

This subcategory comprises textual references to psychological abstractions (e.g. "representations"; "desires") whose ontological existence and operation are described as though located "in the mind." As Billig (1999b) suggests, this use of language must always presuppose the ontological validity of Cartesian dualism i.e. the separation between internal, unobservable mental spaces and the external world of perceptible action. The first extract is selected from Posel's (2005: 127) article entitled "Sex, death and the fate of the nation", and forms part of her argument for why modern sexual identity is always a political phenomenon:

"Meanings and materialities of desire, forms and technologies of pleasure, ways of practising sex, and the sexual identities which attach to all of these, form and re-form within other hierarchies of dominance and the contestations they provoke."

One implication of describing "desire" as having "meanings and materialities", and "pleasure" as having "forms and technologies", is that Posel treats abstract, non-substantive terms (desire and pleasure) in substantive and animistic ways; a description which presupposes that each term has an entity-like existence. 
As Billig (2011) argues, accepting this use of language as a credible form of explanation in the social sciences implicitly condones writing in ways which omit the ascription of agency to human beings - that is, to who it is that might be desiring or experiencing pleasure. Notwithstanding the rhetorical avoidance of specifying what sort of actions human subjects are performing, describing mental phenomena as if they were spatiotemporal objects likewise yields a speculative and/or metapsychological account of the mental, which is neither empirically derivable nor phenomenologically congruous with ordinary subjective experience (Schafer, 1976; Palmer, 1990; Billig, 2011).

As a further excerpt from Posel's article demonstrates, the post-structuralist tendency to, as Palmer (1990: 185) puts it, "descend into discourse" - especially one disposed to subvert the causal efficacy of extra-discursive and material processes - too often risks "re-packaging" complex sets of human actions into reified, autonomous and quasi-intentional forces/agencies:

"In Foucauldian terms, these campaigns incorporate longstanding modem 'techniques of the self' focused centrally and pivotally on sex. With the internalization of sexual regulation, sex becomes the site par excellence of efforts to instil self-discipline through the rational regulation of desire, a technique of self borne of moral reflexivity coupled with a responsiveness to injunctions of rational, responsible behaviour." (Posel, 2005: 134)

The above sentence refers to Posel's description of how modern, Foucauldian "techniques of self" have become ingrained parts of various sexual educational programs, such as loveLife (the in-text example): a non-profit organization that focuses on educating young people about "gender-based violence, substance abuse and teenage pregnancy" (loveLife, 2016; Posel, 2005: 134). However, as per her introductory promise to examine "how sex is put into discourse", Posel $(2005 ; 127)$ writes as if complex psychological behaviours - insofar as they can be described discursively - no longer require (human) subjects of predication. In other words, converting human actions into nominalizations (e.g. "technique of self") allows her to treat them as the grammatical subjects of verbs (e.g. "borne"). And if we consider, in addition to this rhetorical move, the fact that Posel also tends to write in the passive voice, the results become doubly as strange: her descriptions are not only depopulated of humans, but are repopulated with all sorts of non-human processes to which humans themselves must capitulate e.g. of whose "efforts to instil self-discipline" is sex the site par excellence (Posel, 2005: 134)? It is perhaps no mere coincidence then that the twin processes of nominalization (when temporallyindexed processes are re-represented as entities) and passivization (transforming 
the active form of a sentence into a passive one) are often isolated as key features of ideological rhetoric (Fairclough, 2003; Billig, 2011).

Moreover, Posel's reference to the "internalization of sexual regulation" does indeed presuppose the validity of Cartesian dualism, since it implies the existence of some passive process that, by definition, traverses the ontological divide between the exterior world and the interiority of the subject (Stern, 2004). But to what does this implied interiority actually refer? As Wittgenstein (1953, as cited in Stern, 2004) asks in his Philosophical investigations: on what basis does it make sense to infer, let alone hypothesize about, what is ultimately unutterable? If spatiotemporal references to "location, movement, direction, quantity .... are suitable only for things and thing-like entities" - since the only conceivable "inside" is either an imaginary or a fantasied one - it follows that any meaningful talk of "internalization" must be as a means of describing a person who imagines themselves to be incorporating something (Schafer, 1976: 10). Posel's use of language, by contrast, deletes the human source of agency that necessarily grounds all psychological activity; enacting a kind of theoretical reversal in terms of which discourse displaces agency as the sine qua non of subject formation (Palmer, 1990). "Internalization" thus becomes a process that - much like Butler's (1990) notion of performativity - discloses its object only retrospectively, that is, only through the disciplinary practices responsible for retroactively creating the illusion of causal human agency in the first place (Palmer, 1990; Jameson, 1991; Markell, 2003).

Turning now to the use of language in Vice's (2010) article entitled "How do I live in this strange place?", the following analysis attempts to expose a far subtler instance of psychological abstraction and reification. I begin with Vice's (2010: 328-329) explanation of the moral and affective differences between the origins of shame and guilt respectively:

"In standard accounts of the moral emotions, shame differs from guilt in being essentially directed toward the self, rather than outwards toward a harm one brought about. Shame is a response to having fallen below the standards one sets for oneself, whether moral or not. One's very self is implicated in a way that need not be the case with guilt, which is a reaction to what one has done, not primarily to who one is... shame is the recognition that one ought not to be as one is."

In the above paragraph, Vice's use of language presupposes the mutual exclusivity of, on the one hand, the person who feels and, on the other, the feelings themselves. Indeed, her description is not of a person thinking or behaving shamefully. It is rather of a self $a t$ which shame is "directed", or for whom shame arises as "a response" or a "recognition", that is, a self described as both separate from, but still affected by, emotions qua abstract psychological nouns (Vice, 2010: 328). Stated differently, this use of language creates a

PINS [Psychology in Society] 53 • 2017|12 
distinction between "the self" as a metapsychological / metaphysical entity to which properties may be ascribed (an entity structurally identical to the Cartesian mind qua "a thinking thing"), and the thinking, feeling and choosing person at the ontologically irreducible centre of experience (Stolorow \& Atwood, 2016: 185). As the following analysis will demonstrate, this distinction between person and emotion becomes crucial to the persuasiveness of Vice's (2010: 329-330) central thesis that white South Africans ought to feel shame, not about what they do, but about who they are:

"If we are as bad as the thesis of white privilege suggests, then any white person should feel shame, and our obeying this imperative means we are responding as we should, fulfilling at least a moral emotional duty ... [since even] where the self is constituted by injustices it cannot avoid and does not accept voluntarily ... we bear the burden of not being as we should be."

To recapitulate Vice's line of reasoning so far: 1) shame, unlike guilt, is about - or directed toward - who one is; 2 ) who one is, is distinct from - and in this case remains unaffected by - what one does; and 3) white people ought to feel shame (since they "bear the burden of not being as [they] should be) (Vice, 2010: 330). However, that these implicit premises lead to an absurd conclusion can be shown via reductio ad absurdum - literally, reduction (of the premises) of the argument to absurdity: 4) if white people ought to feel shame (premise 3), then they must, in some sense, be morally blameworthy for not feeling shame; 5) to be worthy or deserving of blame presupposes moral agency (i.e. it presupposes that one could have been or done otherwise; or "ought implies can"); 6) therefore white people are morally blameworthy for not feeling shame about something over which they have no agency: who they essentially are. What is absurd, or at least unpalatable, is that white people appear to be morally responsible for feeling the right emotion (shame), but are not morally responsible for its apparent cause, since who they are is something over which they have no agency and so, following premise 5, cannot itself be deserving of blame.

There are two interrelated assumptions in Vice's argument that lead to the above (absurd) conclusion, and which bring us back full circle to the ontological distinction (or rather reification) between person and emotion created by her use of language. The first is just that: separateness, the metapsychological presupposition that the emotionally charged experience of selfhood consists of both a decontextualized and abstracted "self", as well as a set of concretistic emotions to which may be ascribed substantive designations such as location, movement and direction (Schafer, 1976). The second concerns the implied distribution of agency over these respective domains: while the core, abstracted "self" is an immutable entity - an essentialized being - the emotions that encircle it are, if the "moral emotional duty" thesis is to be taken seriously, somewhat controlled by 
volitional acts (Vice, 2010: 329). Taken together, these assumptions render Vice's thesis extremely counterintuitive, since, when adapted to fit her particular premises, white South Africans become blameworthy for not feeling the shame they ought to - and yet, at the same time, are adjudged morally innocent for the shame's apparent cause: not being as they should be.

Vice does attempt to pre-emptively respond to the above objection - albeit not very convincingly. As previously demonstrated via the reductio ad absurdum, the principle that blameworthiness presupposes moral agency, or "ought implies can" (premise 5), is what justifies the moral innocence of white people for not being as they should be. Vice, however, rejects the validity of this widely accepted moral maxim in the case of white South Africans. She argues instead that whites are still blameworthy for not being as they should be, despite the fact that they cannot but be as they (currently) are. Indeed, she justifies this by claiming that given white people's unavoidable privilege and "insidious connection with injustice ... some version of the principle of 'ought implies can' needs to be rejected or revised" (Vice, 2010: 328-329). If this revision were accepted, however - and subsequently applied to her own argument - then Vice's previous claim (premise 3) that white South Africans ought to feel shame (and that they are blameworthy for not feeling so), would not necessitate its own logical possibility. That is to say, feeling shame need not represent an attainable (possible) moral position for white people, since one might equally regard it as a merely quixotic proposal with no actual moral weight.

By the same token, Vice's later recommendation - namely that whites ought to be politically silent - would suffer a similar utopian fate (Vice, 2010). If these are logically defensible consequences that follows from the terms of Vice's own argument, then one might also conclude, and not without reason, that her paper is tantamount to, and indeed no more relevant than, an abstract exercise in moral theorizing. On the other hand, if Vice were to selectively apply the standard "ought implies can" principle to one part of her argument but not the other, then her account becomes at best question begging (i.e. fails to justify why the standard "ought implies can" principle is applicable in some instances but not others) and at worst, logically inconsistent.

\section{External agencies: Nominalization and anthropomorphism}

The focus of this sub-category is on the use of language where relational processes, abstract categories and social phenomena are transformed, frequently via the authorial act of nominalization, into reified constructs that are presupposed to have a stable spatiotemporal existence. While the relevant concern remains the attribution of agency to non-human entities, emphasis is placed on descriptions in which supra-individual constructs are anthropomorphized - thereby acquiring a "phantom objectivity" that is likewise taken as the self-sufficient source of agency (Sayer, 1989: 30). This section 
begins with an analysis of the use of language in Steyn and Foster's (2008) "Repertoires for talking white: Resistant whiteness in post-apartheid South Africa":

"In this new context, the central question for whiteness, as the orientation which takes its privilege as normal and appropriate, can be put simply: how to maintain its advantages in a situation in which black people have legally and legitimately achieved political power." (Steyn \& Foster, 2008: 26)

For the purposes of this discussion, and in order to maintain theoretical consistency, the concept of "whiteness" will be defined using Steyn's (2005: 121) own words from a chapter written three years prior:

"[Whiteness] is best understood as an ideologically supported [emphasis added] social positionality that has accrued to people of European descent as a consequence of the economic and political advantage gained during and subsequent to European colonial expansion ... [it] is the shared social space in which the psychological, cultural, political and economic dimenions of this privileged positionality are normalized, and rendered unremarkable."

In what meaningful sense can whiteness, when defined as a "social positionality" or a "social space", be described as an "orientation which takes" or which "maintain(s) its advantages" (Steyn, 2005: 121; Steyn \& Foster, 2008: 26)? If indeed whiteness is a concept that describes a person's historically contingent relationship with the material world, then it is surely erroneous to construe it as separable in its own right, since that entails reifying the relational dimension of whiteness, transforming it into a "self-determining concept" which acts on behalf of, and thus as though it were, a subject (Sayer, 1989: 32). In other words, describing whiteness as if it were a social agency obscures the fact that it is not constitutive of social subjects, but rather expressive of said subjects historically contingent relation with the external world. Notably, this process of nominalization, and of which reification is its conceptual counterpart, has long been criticized by Marxist scholars for its palpable ideological potential (Petrović, 1983).

According to György Lukács, the renowned Marxist philosopher, this process of theoretical abstraction (where the material sources of human agency are obscured through the transformation of "human properties, relations and actions into properties, relations and actions of reified abstractions"), amounts to a denial of the dialectical materialist premise that "it is not men's consciousness that determines their existence, but on the contrary, their social existence that determines their consciousness" (Petrović, 1983: 411; Marx, 1859, para. 5, as cited in Sayer, 1989: 32). As a second excerpt from Steyn and Foster (2008: 27) shows, the rhetorical habit of nominalization is of particular significance 
in contexts where the obfuscation of human agency has indirect political consequences:

"In other words, the dominant white representations of contemporary South Africa attempt to 'fix' groups relative to each other, reproducing and extending the power structures of whiteness into post-apartheid South African society."

It is presupposed in the above sentence that there exists such a thing as a "white representation of contemporary South Africa" (Steyn \& Foster, 2008: 27). By implication then, according to the same identitarian logic, there also exists such a thing as a "black representation" of contemporary South Africa, since, as Norval (1994: 120) explains, "all identity is constituted through an externalization of the other via the drawing of political frontiers." In other words, the positive characteristics that define "who or what I am" always already presuppose that which stands external to "my" relative vantage point, a necessary "other" whose difference encapsulates "who or what I am not" (Norval, 1994). Moreover, as we have seen, it is not representations (the abstract noun) that "attempt", "reproduce" or "extend"; since these are predicates of people not abstractions. Indeed, attributing agency to such abstractions not only obscures who is in fact "representing", but further suggests, a priori, that the content of any representation (e.g. moral, political) is necessarily co-extensive with the racial identity of the person who offers it (Norval, 1994).

Though only implied, this a priori correspondence between the abstraction and the actual forms of consciousness signified by that abstraction, is arguably a consequence of privileging the former (i.e. white representation) as it exists in discursive relations, over the question of its material, extra-discursive production (Sahay, 1998). Steyn and Foster (2008) thus indirectly foreclose an examination of the shifting frontiers (political, economic, spatial etc.) that, at any particular historical moment, semantically stabilize the salient differences between social identities (Sahay, 1998). In other words, the authors are only able to meaningfully position (white) "identity" in the analytic foreground - and as a fixed socio-political category in post-apartheid S.A - because social "difference" is presupposed as its historically static background. Set within this framework, the authors' ideological work can be understood - not as a form of "false consciousness" (the classical Marxist view) - but as a kind of "tacit denial that ideas and beliefs are specific to a particular time, place and social group" (Eagleton, 1991, p.59).

Throughout their article, Steyn and Foster (2008) repeatedly commit the fallacy of misplaced concreteness (reification), producing abstract social entities which they then (almost as frequently) anthropomorphize in a manner that perpetually obfuscates the material sources of human agency (Sayer, 1989). I will provide two more examples of this 
use of language in Steyn and Foster (2008), before briefly returning to address the same issue in Posel (2005):

"By denying the effects of racialization, colour blindness is a powerful mechanism in building white consensus and enabling the reproduction of racism." (Steyn \& Foster, 2008: 29)

Is "colour blindness" capable of "denying"? Surely not. Rather we should say that, at least in this case, "colour blindness" is constitutive of someone's denying the social existence of someone else's racial identity. A similar objection applies to the authors' use of language just four pages later:

"Resistant whiteness does hesitate to present itself as the conscience of the nation." (Steyn \& Foster, 2008: 33)

Here again, "whiteness" is construed as an autonomous agency, as an abstraction whose self-determining nature belies its own origins in the patterned, though never uniform, activity of a certain social group (Norval, 1994). All this suggests that Steyn and Foster's (2008) language is to some degree essentializing, since what remains absent in their account is an acknowledgement of what follows from the changing interrelationships between the particular determinants of identity (e.g. race, class, gender): in this case, that "whiteness" - as a marker of normalized privilege - has no essential, ahistorical property that necessarily consigns its discursive relevance to the margins of the white racial identity (Laclau, 1994).

As is gradually becoming clearer, the simplified equivalence of whiteness with privilege, and therefore of non-whiteness with oppression, risks downplaying the growing asymmetry in this country between the haves and the have-nots, a fact that has more to do with a perpetually unjust economic system, than with race as a principle organizing factor (Long, 2016a). Indeed, the growth of South Africa's black middle class, which according to University of Cape Town marketing professor John Simpson (2016, as cited in Brown, 2016, para. 1) "has more than trebled over the past 12 years" (up to approximately 6 million people), is perhaps a cogent reminder that insofar as leftist politics today is concerned - the simple conflation of race and class no longer holds strong.

Lastly, it is worth briefly noting how Posel's (2005) use of language evidences a similar tendency to reify and anthropomorphize human social relations, transforming them into autonomous processes that come to be regarded as beyond the realm of human agency (Chari, 2010): 
"The cultural logic of late capitalism - particularly its valorization of the pleasures of consumption (Altman 2001; Hennessy 2000) - articulates closely with national trajectories of class and status formation. (Posel, 2005: 131)

But "the cultural logic of late capitalism" is not a subject, as it cannot valorize "the pleasures of consumption" (Posel, 2005: 131). Only people are capable of performing such actions. By implying that it is an economic system that valorizes, Posel's use of language reinforces the distinction - frequently criticized as an ideologically supported false dichotomy - between subjective human activity and the ostensibly "objective", self-grounding operations of the market (Chari, 2010).

So far, the analysis of language has revealed how human agency may be obfuscated (e.g. nominalization), misattributed (e.g. metapsychological reification; anthropomorphism) and alienated from its true sources (e.g. Vice's ontologically separated "self" and "emotion"). Indeed, there appears to exist (for lack of a better phrase) a particular "theoretical climate" in which questions dealing with social identity, racial difference and their attendant moral and psychological dimensions are advanced on the basis of a presupposed ontology of non-human agents. Yet, irrespective of one's metaphysical commitments, any ontology that "refers to the abstract and non-substantive in substantive, animistic and anthropomorphic terms" cannot but be conceptually confused; after all, to substitute relations among humans with relations among things is surely to experience the world almost never as one's own (Schafer, 1976: 124).

\section{Category 2: Agency as a property of antecedently given identities}

In contrast to the first, the second main category focuses on the use of language where the exercise of agency is correctly (or rather coherently) ascribed to human subjects. However, a unique emphasis is now placed on the identity-based nature of the political subject which grounds the legitimate exercise of agency. More specifically, I focus on the use of language in which agency is construed as something that is exercised by subjects with already fully formed political identities (i.e. subjects with discrete, self-enclosed political identities). Consequently, the following analysis highlights the existence of a particular diagnosis of social and political domination/oppression, namely, one where correcting injustice (or producing social change) necessarily entails treating agency only as a property of subjects with antecedently given political identities.

\section{Realist view of political identity}

The focus of this subcategory is on the "realist" view of identity: that is, the view that identities are independently existing social facts that we simply perceive with greater or lesser degrees of accuracy (Markell, 2003). An example of this realist view of identity can be found in the use of language in Dixon, Durrheim and Tredoux's (2005: 703) 
influential paper entitled "Beyond the optimal contact strategy: A reality check for the contact hypothesis":

"We advocate that more research be conducted on the mundane, seemingly unimportant, encounters that constitute the overwhelming majority of everyday contact experiences [between groups]."

Subsequent to this suggestion, the authors immediately refer to an earlier study by Dixon and Durrheim (2003), which "observed day-to-day relations on a beach in postapartheid South Africa", as an "instructive example" of this kind of research (Dixon, Durrheim \& Tredoux, 2005: 703). Citing the results of this earlier study, the authors then state that:

"[...] the demographic composition of the beach seemed to reflect the racial diversity of South African society, with about $64 \%$ of occupants being classified as Black, $24 \%$ as White, $10 \%$ as Indian, and $2 \%$ as colored." (Dixon, Durrheim \& Tredoux, 2005: 703)

In the above passage, the authors appear to inherit the apartheid era definition of "race" - the fundamental criterion of which was physical appearance/skin colour (Population Registration Act No.30, 1950). According to this definition, racial identity is treated as a pre-given fact (i.e. as something that exists independently of empirical observation), and thereby conforms to the realist view of identity. In addition to its essentialising bent (an ontological concern), the major political consequence of the realist view is that it may be used to support an understanding of social injustice as "a matter either of the exclusion of otherness or the assimilation of the other to the same" (Markell, 2003: 24). In certain circumstances, ameliorating forms of racial discrimination that are reinforced by exclusionary social arrangements may well result in favourable improvements in the lives of those previously subordinated. However, what is perhaps less obvious is that, by treating identities as independently existing (and therefore antecedently given) facts about people, we presuppose too that the existing power relations and social structures - which form the very historical conditions of possibility for the politicization of different identities - are inevitable, self-grounding and impervious to human action (Sahay, 1998; Markell, 2003). Consequently, the scope of agency required to effect social change is de facto limited to the inter-subjective realm; not because subjects necessarily lack the ability to change the existing power structures (e.g. capitalism), but because social change is not construed in terms of structural change. Indeed, support for this latter claim is provided by the authors' following contention just one page later:

"In the absence of detailed information about these kinds of banal contacts, social psychologists cannot ... formulate realistic programs of social intervention ... they cannot appreciate the nature and variety of ordinary encounters between groups and, 
by implication, the full range of situations in which interventions can, or should, be attempted. Nor can they understand the impediments that lie in the path of meaningful social change." (Dixon, Durrheim \& Tredoux, 2005: 704)

If the absence of detailed information about the banal contacts between social groups prevents social psychologists from understanding the obstacles to social change, then - by reverse implication - understanding such obstacles necessarily entails having knowledge about the banal contacts between social groups. But what kind of conception of social change necessitates having knowledge about banal intergroup contact? If the answer is not one that is inconsistent, then what it presupposes (i.e. antecedently given social/political identities) cannot itself be rendered unstable by the nature of the social change so conceived. Stated differently, if we claim that a social order is unjust (and requires change), it must be with reference to a metric that the social order itself does not construct (Chibber, 2013). Indeed, this demonstrates again why the authors' conception of social change is in fact limited to one in which most forms of social antagonism become reducible to intergroup/inter-subjective hostilities.

\section{Constructivist view of political identity}

The focus of this subcategory is on the "constructivist" view of identity: namely, the view that identities are brought into existence through performative utterances and actions (Stern, 2004). In contrast to the realist view, according to which identities are simply facts that we come to know (i.e. their existence is presupposed), identities in the constructive sense are actively constituted by modes of action or "doing" (Markell, 2003). Consequently, identities are not understood to reflect some underlying social reality, rather, their truth or falsity is a matter of normative evaluation that is itself based on "the ways in which we are perceived and characterized by others" (Markell, 2003: 59). An identity is therefore "true" only in the sense of being produced by mutually respectful and affirmative relations between individuals and/or groups in society (McQueen, 2015). Arguably, the use of language in Hook's (2005) "A critical psychology of the postcolonial" exemplifies this particular view of identity. After extending praise to Biko (1978) for providing, in a similar fashion to Fanon, "another way of operationalizing a politics of the psyche", Hook (2005: 485) offers the following laudatory remark:

"As such, the challenge of Black Consciousness $[B C]$ was to reverse the colonial imprint of a negative, racist self-image, and to replace it with a positive, more self-affirming - if not angry-forms of black identity and history. Importantly, 'blackness' here - and this is crucial point, particularly against contentions of essentialism - was not simply an issue of skin color, but was a form of solidarity, a collective form of hope and security, a way for black people to 'build up their humanity' (Biko, cited in Arnold, 1979: 34). Emphatically then, we are not speaking here of a unified psychology of black 
essences, but a psychology based on disruptive historical experiences of oppression and marginality." (Hook, 2005: 486)

On this view, political identities are seen as the products of inter-subjective acts of recognition, or indeed misrecognition - in other words, as the products of social interactions that either succeed or fail "to extend to people the respect or esteem they deserve" (Markell, 2003: 18). This accounts for the fact that identity construction is at once a political affair, since the normative act of misrecognition (which, in extreme cases, may express a denial to recognize as such) likewise functions as a descriptive act of representation. Perhaps it also explains why Hook (2005) is keen to emphasize that the project of BC - namely, the reclamation of positive and self-affirming forms of black identity - was fundamentally about the restoration of political identity, and hence radically opposed to any essentialized notion of "blackness" per se. Indeed, the opposition alluded to here would seem to parallel the distinction between the constructivist and realist views of identity. The problem, however, is that such a distinction collapses upon further inspection, for in Hook's framework - as in Biko's - the demand to be recognized (whether by those from different or comparable backgrounds) for who one is, or for who one has self-determined oneself to be, is already to invoke identity as some antecedently given fact (Markell, 2003). In other words, the constructivist view collapses back into the realist view by dint of its circular logic: the definition of a positive black identity, for example, is both produced, as well as presupposed, by the acts of recognition and affirmation that mark it out as - in Hook's (2005: 286) words - "a collective form of hope and security". It may well be therefore that the same limitations of the realist view (e.g. regarding social change) apply to the constructivist view too.

Before concluding, it could be said that too stringent a focus on the ontology of identity in Hook's account misses the mark, obscuring what an otherwise more charitable reading might admit: that his argument is mostly concerned with identity as the instrument of a strategic politics. As he later reiterates:

"[...] the drive to overcome political oppression through collective effort is not simply a psychological 'formula of identity' (Kros, 1999) - the project here is exactly that of political identity: the use of identity as a kind of weapon, as political instrument. The psychological means of articulating this envisaged self are hence useful precisely inasmuch as they further this end, and not beyond." (Hook, 2005: 489)

Whether or not identity proves politically successful when used in this way is surely a question that requires empirical or sociological investigation. The perennial risk, however, is that strategic identity-based politics - especially those that work only to 
"include" the plurality of determinate groups previously "excluded" - become no less than a struggle to occupy the "more-subaltern-than-thou" position of reversed privilege (Reed, 2009). The logic of collective identification, in other words, perpetually risks devolving into an endless differentiation of individual privilege, fracturing any political momentum in its wake; intersectionality theory operationalized as political praxis may be a leading candidate in this regard (Ertel, 2015). From a more theoretical standpoint, even if the constructivist emphasis succeeds in problematizing the naturalness of identity, the more arduous work of directing attention to, actively challenging and subsequently altering the socio-historical structures in which identity is used as a means to justify exploitative relations remains undone (Sahay, 1998; Zizek, 2006; Reed, 2009; Chibber, 2013). What it does contribute to, conversely, is the reified illusion that the latter structures are permanently fixed - and lie beyond the realm of human agency tout court (Sayer, 1989).

\section{Conclusion}

My principal aim here will be to explicate the conceptual relationships between the different categories that have emerged from the data analysis. My first question begins with the internal, conceptual relationship between the last two subcategories (which together make up the second main category). Judging from the analysis and discussion, it seems that the use of language in both subcategories share an account of social change that is (mostly) "immanent" to the existing social order itself. To critique the existing hierarchies of political, cultural and discursive representation (e.g. to treat identities as antecedently given facts) - intentions notwithstanding - is to forgo challenging the now global structures of domination within which any social locality is implicated, and through which the political identities of its members are themselves reproduced (Sahay, 1998). How might this relate to the non-human ontology of agents identified in the first main category? If what is entailed by an immanent account of social change is indeed mass capitulation to an image of a static, deterministic and permanent socio-economic structure, then what become apparently unchangeable too are the law-like patterns (e.g. market forces) and social phenomena (e.g. techniques of self) that come to assume an existence independent of their productive human sources.

In other words, the non-human ontology of agents gains the appearance of an autonomous, self-governing realm precisely because it is based on the abstraction of contingent - and therefore alterable - human social relations. Stated differently, this ontology of agents represents the outcome of a particular linguistic conversion: namely, when the open-ended temporality of human action is spatialized using concepts that grammatically exclude reference to tense and/or modality - and therefore also to contingency (e.g. whiteness) (Markell, 2003). It is what Shapiro (2001: 113) calls "turning a dynamic of existence into a territorial fixity". It would appear to be no mere coincidence 
that the foregoing connections have been drawn before, principally by Marx himself. As Eagleton (1991: 70) suggests:

"In certain social conditions, Marx argues, human powers, products and processes escape from the control of human subjects and come to assume an apparently autonomous existence. Estranged in this way from their agents, such phenomena then come to exert an imperious power over them, so that men and women submit to what are in fact products of their own activity as though they are an alien force. The concept of alienation is thus closely linked to that of reification - for if social phenomena cease to be recognizable as the outcome of human projects, it is understandable to perceive them as material things, and thus to accept their existence as inevitable."

One of the most pressing questions raised by research of this kind is thus how to begin reforming the current "immanent" critiques offered by leftist politics today. What appears to be required is a trans-disciplinary approach concerned with explaining manifest social antagonisms (e.g. class oppression; institutional racism; Islamophobia) in terms of the global historical and material conditions within which they are located. In this regard, the point may be that political identities should be viewed - not as pre-given social facts, nor as wholly discursive entities - but as relations between people that express certain higher order, or structural, relations of privilege and subordination. As such, one ought to attempt, first and foremost, to dismantle the latter (seemingly fixed) relations; not just relocate subordinate groups at the privileged end. Moreover, as we have seen, identities qua relations have material and historical conditions of possibility. It may well be, therefore, that the appeal of contemporary forms of identitarian politics derives from a kind of "felt determinism" whereby what is presupposed is precisely that such conditions are utterly unalterable. Perhaps then, as a discipline concerned with psychological well-being, we would be remiss to ignore the latent, pervasive resignation that fuels the plurality of battles fought on the plain of identity and difference (Chibber, 2013). To this end, a critical and historical engagement with the phenomena of reification, alienation and the sociogenetic bases of psychopathology can only but strengthen the imaginative theory required of the left today (Bulhan, 1985; Long, 2016b).

\section{References}

Alcoff, L M (2000) Who's afraid of identity politics?, in Moya, P \& Hames-García, M (eds) Reclaiming identity: Realist theory and the predicament of postmodernism ( $p p$ 312-344). Berkeley: University of California Press. 
Allen, A (2002) Power, subjectivity and agency: Between Arendt and Foucault. International Journal of Philosophical Studies, 10(2), 131-149.

Ansell-Pearson, K (1991) Nietzsche on autonomy and morality: The challenge to political theory. Political Studies, 39, 270-286.

Barnard-Wills, D (2012) Surveillance and identity: Discourse, subjectivity and the state. Farnham: Ashgate.

Biko, S (1978) I write what I like. London: Bowerdean.

Billig, M. (1999a) Commodity fetishism and repression: Reflections on Marx, Freud and the psychology of consumer capitalism. Theory \& Psychology, 9(3), 313-329. DOI: $0.1177 / 0959354399093003$

Billig, M (1999b) Freudian repression: Conversation creating the unconscious. Cambridge: Cambridge University Press.

Billig, M (2011) Writing social psychology: Fictional things and unpopulated texts. British Journal of Social Psychology, 50(1), 4-20. DOI: 10.1111/j.20448309.2010.02003.x.

Brown, J (2016, 28 August) Black middle class floating the economy. City Press. Retrieved from: http://city-press.news24.com/Business/black-middle-class-floatingthe-economy-20160826

Bulhan, H A (1985) Frantz Fanon and the psychology of oppression. New York: Plenum Press.

Butler, J (1990) Gender trouble: Feminism and the subversion of identity. New York: Routledge.

Chari, A (2010) Toward a political critique of reification: Lukács, Honneth and the aims of critical theory. Philosophy \& Social Criticism, 36(5), 587-606. DOI: $10.1177 / 0191453710363582$

Chibber, V (2013) Postcolonial theory and the specter of capital. London: Verso.

Ci, J (2011) Evaluating agency: A fundamental question for social and political philosophy. Metaphilosophy, 42(3), 261-281. 
Culler, J (1976) Presupposition and intertextuality. Comparative Literature, 91(6), 1380-1396.

Degano, C (2007) Presupposition and dissociation in discourse: A corpus study.

Argumentation, 21, 361-378. DOI: 10.1007/s10503-007-9058-7

Dixon, J \& Durrheim, K (2003) Contact and the ecology of racial division: Some varieties of informal segregation. The British Journal of Social Psychology, 42, 1-23.

Dixon, J, Durrheim, K \& Tredoux, C (2005) Beyond the optimal contact strategy: A reality check for the contact hypothesis. The American Psychologist, 60(7), 697-711. DOI:

10.1037/0003-066X.60.7.697

Eagleton, T (1991) Ideology: An introduction. London: Verso.

Ertel, J (2015) Liberal multiculturalism and the political economy of identity politics.

Social Movement Studies (Analysis). Retrieved from: http://www.hamptoninstitution. org/identity-incorporated.html\#.V9V1B_197IW

Fairclough, N (2003) Analysing discourse: Textual analysis for social research. London: Routledge.

Frankenberg, R (1993) Questions of culture and belonging, in White women, race matters: The social construction of whiteness (pp 191-235). Minneapolis: University of Minnesota Press.

Frueh, J (2003) Political identity and social change: The remaking of the South African social order. Albany: State University of New York Press.

Goodwin, C J (2010) Research in psychology: Methods and design. New York: Wiley \& Sons.

Häkli, J \& Kallio, K P (2014). Subject, action and polis: Theorizing political agency. Progress in Human Geography, 38(2), 181-200.

Heyes, C (2014) Identity politics, in Zalta, E N (ed) The Stanford encyclopedia of philosophy. Retrieved from: http://plato.stanford.edu/archives/win2014/entries/ identity-politics/ 
Honneth, A (1995) The struggle for recognition: The moral grammar of social conflicts. Cambridge: Polity Press.

Hook, D (2005) A critical psychology of the postcolonial. Theory \& Psychology, 15(4), 475-503.

Hook, D (2011) Retrieving Biko: A Black Consciousness critique of whiteness. African Identities, 9(1), 19-32. DOI: 10.1080/14725843.2011.530442

Jameson, F (1991) Postmodernism, or, the cultural logic of late capitalism. Durham: Duke University Press.

Kaniki, A (1999) Doing an information search, in Terre Blanche, M J \& Durrheim, K (eds) Research in practice: Applied methods for the social sciences (pp 17-28). Cape Town: University of Cape Town Press.

Keenan, E (1972) On semantically based grammar. Linguistic Inquiry, 3, 413-62.

Lacan, J (2006) The mirror stage as formative of the I function as revealed in psychoanalytic experience (1949-French), in Écrits: The first complete edition in English. (Fink, B trans.). New York: W.W. Norton \& Company.

Laclau, E (ed) (1994) The making of political identities. London: Verso.

Long, W (2015, 17 June) Self-interest the foe of authentic change. Cape Times, 9.

Long, W (2016a) On the Africanization of psychology [Editorial]. South African Journal of Psychology, 46(4), 1-3. DOI: 10.1177/0081246316650853

Long, W (2016b) 'Race' or class? In search of imaginative theory. Amandla!, 48, 28-29. Retrieved from: https://www.academia.edu/29438118/Race or class In search of imaginative theory

loveLife South Africa (2016). Overview of loveLife. Retrieved from: http://lovelife.org. za/overview-of-lovelife/

Markell, P (2003) Bound by recognition. Princeton, NJ: Princeton University Press.

McNay, L (2010) Feminism and post-identity politics: The problem of agency.

Constellations, 17(4), 512-525. 
McQueen, P (2015) Subjectivity, gender and the struggle for recognition. Basingstoke, England: Palgrave MacMillan.

Nabers, D (2015) A poststructuralist discourse theory of global politics. New York: Palgrave Macmillan.

Norval, A (1994) Social ambiguity and the crisis of apartheid, in Laclau, E (ed) The making of political identities ( $\mathrm{pp}$ 115-137). London: Verso.

Palmer, B D (1990) Descent into discourse: The reification of language and the writing of social history. Philadelphia: Temple University Press.

Parliament of South Africa (1950) Population Registration Act: No. 30 of 1950.

SA Government Printer. Retrieved from: https://en.wikisource.org/wiki/ Index:Population_Registration_Act_1950.pdf

Petrović, G (1983) Reification, in Bottomore, T, Harris, L, Kiernan, V G \& Miliband, R (eds) A Dictionary of Marxist Thought (pp 411-413). Cambridge, MA: Harvard University Press.

Porter, J E (1986) Intertextuality and the discourse community. Rhetoric Review, 5(1), 33-47.

Posel, D (2005) Sex, death and the fate of the nation: Reflections of the politicization of sexuality in post-apartheid South Africa. Africa: Journal of the International African Institute, 75(2), 125-153. Retrieved from: http://www.jstor.org/stable/3556816

Reed, A J (2009) The limits of anti-racism. Left Business Observer, 121. Retrieved from: http://leftbusinessobserver.com/Antiracism.html

Sahay, A (1998) Transforming race matters: Towards a critique-al cultural studies.

Cultural Logic: An electronic Journal of Marxist Theory and Practice, 1(2). Retrieved from: http://clogic.eserver.org/1-2/sahay.html

Sayer, D (1989) The violence of abstraction: The analytic foundations of historical materialism. Oxford: Basil Blackwell.

Schafer, R (1976) A new language for psychoanalysis. New Haven: Yale University Press. 
Shapiro, M J (2001) For moral ambiguity: National culture and the politics of the family. Minneapolis: University of Minnesota Press.

Sharansky, N (2008) Defending identity: Its indispensable role in protecting democracy. New York: Public Affairs.

Sher, D \& Long, W (2012). Historicizing the relevance debate: South African and American psychology in context. South African Journal of Psychology, 42(4), 564-575. DOI: $10.1177 / 008124631204200410$

Stern, A (1967) Sartre, his philosophy and existential psychoanalysis. New York: Dell Publishing Co.

Stern, D G (2004) Wittgenstein's Philosophical Investigations: An introduction. New York: Cambridge University Press.

Steyn, M (2005) "White talk": White South Africans and the management of diasporic whiteness, in López, A J (ed) Postcolonial whiteness: A critical reader on race and empire ( $p p$ 119-135). Albany: State University of New York Press.

Steyn, M \& Foster, D (2008) Repertoires for talking white: Resistant whiteness in post-apartheid South Africa. Ethnic and Racial Studies, 31(1), 25-51.

Stolorow, R D \& Atwood, G E (2016) Experiencing selfhood is not "a self". International Journal of Psychoanalytic Self Psychology, 11(2), 183-187. DOI: 10.1080/15551024.2016.1141611

Taylor, C (1994) The politics of recognition, in Gutmann, A (ed) Multiculturalism: Examining the politics of recognition ( $p p$ 25-73). Princeton: Princeton University Press.

Taylor, C (1995) Overcoming epistemology, in Philosophical arguments (pp 1-19). Cambridge, MA: Harvard University Press.

Vice, S (2010) "How do I live in this strange place?". Journal of Social Philosophy, 41(3), 323-342. DOI: 10.1111/j.1467-9833.2010.01496.x

Yule, G (1996) Pragmatics. Oxford: Oxford University Press.

Žižek, S (2006) The universal exception. London: Continuum. 
Žižek, S (2013) Review of Vivek Chibber's (2012) book, Postcolonial theory and the specter of capital. Retrieved from: https://www.versobooks.com/books/1158postcolonial-theory-and-the-specter-of-capital

\section{Appendix A}

Definition of presupposition: "any kind of background assumption against which an action, theory, expression or utterance makes sense or is rational" (Levinson, 1983: 168, as cited in Degano, 2007: 363).

\section{Constancy under negation - the fundamental semantic rule in the identification of a} presupposition: A sentence $S$ logically presupposes a sentence $S^{\prime}$ just in case $S$ logically implies S' and the negation of S, namely S, also logically implies S' (Keenan, 1972: 45).

Example: The sentences, "my dog is hairy" and "my dog is not hairy", both presuppose that I have a dog.

Nominalization: "When processes are represented as entities by transforming clauses (including verbs) into a type of noun. For instance, 'employees produce steel' is a non-metaphorical representation of a process, whereas 'steel production' is a metaphorical, nominalized representation. As this example shows, nominalization often entails excluding social agents in the representation of events (in this case, those who produce). It is a resource for generalizing and abstracting which is indispensable in, for instance, science, but can also obfuscate agency and responsibility." (Fairclough, 2003: 220) 